In Situ

Revue des patrimoines

\section{In Situ}

Revue des patrimoines

18 | 2012

Le cheval et ses patrimoines (1ère partie)

\title{
Pour une nouvelle équitation à la française
}

\section{Patrice Franchet d'Espèrey}

\section{OpenEdition}

Journals

Édition électronique

URL : http://journals.openedition.org/insitu/9758

DOI : $10.4000 /$ insitu.9758

ISSN : 1630-7305

\section{Éditeur}

Ministère de la culture

\section{Référence électronique}

Patrice Franchet d'Espèrey, «Pour une nouvelle équitation à la française », In Situ [En ligne], 18 | 2012, mis en ligne le 01 août 2012, consulté le 22 avril 2019. URL : http://journals.openedition.org/ insitu/9758 ; DOI : 10.4000/insitu.9758

Ce document a été généré automatiquement le 22 avril 2019

\section{(c) (i) (9)}

In Situ Revues des patrimoines est mis à disposition selon les termes de la licence Creative Commons Attribution - Pas d'Utilisation Commerciale - Pas de Modification 4.0 International. 


\section{Pour une nouvelle équitation à la française}

\section{Patrice Franchet d'Espèrey}

1 L'équitation savante, élaborée en France depuis le XVI ${ }^{\mathrm{e}}$ siècle et le retour d'Italie des écuyers qui avaient fréquenté les académies, cultive l'ambition de retrouver, sous le cavalier, la beauté des allures et des attitudes du cheval lorsqu'il se meut en liberté...

2 Voir le site: http://equitation-francaise-baucher.fr/index.php/pour-une-nouvelleequitation-a-la-francaise

\section{AUTEUR}

\section{PATRICE FRANCHET D'ESPÈREY}

Institut français du cheval et de l'équitation patrice.franchetdesperey@cadrenoir.fr 